Contributions:

A Study design/planning

B Data collection/entry

C Data analysis/statistics

D Data interpretation

E Preparation of manuscript

F Literature analysis/search

$\mathrm{G}$ Funds collection

\title{
POSTLINGUAL SENSORINEURAL HEARING LOSS DUE TO A VERY RARE COCH PATHOGENIC VARIANT
}

\section{Dominika Ozieblo 1,2ABCDEF, Grazyna Tacikowska ${ }^{3 B C D E}$, Henryk Skarzynski ${ }^{4 B E G}$, Monika Oldak ${ }^{1 A B C D E F G}$}

${ }^{1}$ Department of Genetics, Institute of Physiology and Pathology of Hearing, Warsaw, Poland

${ }^{2}$ Postgraduate School of Molecular Medicine, Medical University of Warsaw, Warsaw, Poland

${ }^{3}$ Department of Otoneurology, Institute of Physiology and Pathology of Hearing, Warsaw, Poland

${ }^{4}$ Oto-Rhino-Laryngology Surgery Clinic, Institute of Physiology and Pathology of Hearing, Warsaw, Poland

Corresponding author: Monika Ołdak, MD, PhD, Department of Genetics, World Hearing Center, Institute of Physiology and Pathology of Hearing, Mokra 17, Kajetany, 05-830 Nadarzyn, Tel.: +48-22-356-03-66; Fax: +48-22-356-03-67; e-mail: m.oldak@ifps.org.pl

\begin{abstract}
Background: The $\mathrm{COCH}$ gene encoding cochlin is highly expressed in the inner ear but the exact physiological function of the protein still remains unknown. Pathogenic variants located in $\mathrm{COCH}$ cause autosomal dominant hearing loss with possible vestibular involvement.

Material and methods: A five-generation Polish family with autosomal dominant hearing loss and tinnitus was recruited for the study. Audiological and vestibular assessments were conducted and clinical exome sequencing was performed in the index patient. Next, co-segregation of the detected variant with hearing loss in the family was confirmed using Sanger sequencing.

Results: All affected individuals presented postlingual, progressive hearing loss mainly affecting high frequencies. No vestibular dysfunction was detected. In this study, we have identified a very rare $\mathrm{COCH}$ p.Ile374Thr pathogenic variant that segregated with the disease.

Conclusions: Our study provides an independent confirmation of the pathogenic role of $\mathrm{COCH}$ c.1115T>C in hearing loss. In addition to hearing loss, individuals with $\mathrm{COCH}$ pathogenic variants may also suffer from tinnitus and vertigo.

\section{HIPOACUSIA NEUROSENSORIAL POSTLINGUAL CAUSADA POR UNA VARIANTE PATOGÉNICA RARA EN EL GEN COCH}

\section{Resumen}

Introducción: El gen $\mathrm{COCH}$ que codifica la cochlina es altamente expresado en el oído interno, sin embargo, la función fisiológica exacta de la proteína codificada por este gen sigue permaneciendo desconocida. Las variantes patogénicas localizadas en el gen $\mathrm{COCH}$ causan hipoacusia heredada según un patrón autosómico dominante que puede afectar el sistema vestibular.

Materiales y métodos: Para el estudio se reclutó una familia polaca de cinco generaciones con una hipoacusia que sigue el patrón autosómico dominante y tinnitus. Se evaluó la función del sistema vestibular-coclear y a partir de la muestra de ADN se llevó a cabo la secuenciación clínica del exoma. A continuación, en la familia estudiada se realizó un análisis de la segregación de las variantes genéticas detectadas con la hipoacusia.

Resultados: Todos los miembros de la familia examinada presentaron hipoacusia de tipo postlingual y progresivo, que sobre todo afectaba las altas frecuencias. No se detectaron trastornos del funcionamiento del sistema vestibular. En las pruebas genéticas, se identificó una variante patogénica muy rara p.Ile374Thr en el gen $\mathrm{COCH}$, que segregaba completamente con la enfermedad.

Conclusiones: Nuestro estudio constituye una confirmación independiente del papel patogénico de la variante p.Ile374Thr en el gen $\mathrm{COCH}$ en el desarrollo de la hipoacusia. Aparte de la hipoacusia, los pacientes con variantes patogénicas en el gen $C O C H$ pueden también experimentar tinnitus y trastornos del equilibrio.

Palabras clave: $\mathrm{COCH}$, DFNA9, hipoacusia autosómica dominante, secuenciación de segunda generación 


\section{ПОСТЛИНГВАЛЬНАЯ ПЕРЦЕПТИВНАЯ ТУГОУХОСТЬ, ВЫЗВАННАЯ ОЧЕНЬ РЕДКИМ ПАТОГЕННЫМ ВАРИАНТОМ СОСН}

\section{Изложение}

Введение: Ген СОСН, кодирующий кохлин, имеет высокую экспрессию во внутреннем ухе, но точная физиологическая функция кодируемого этим геном белка по-прежнему остаётся неизвестной. Патогенные варианты, локализованные в гене СОСН, вызывают тугоухость с аутосомно-доминантным типом наследования, с возможным поражением вестибулярной системы.

Материал и методы: В исследования была вовлечена семья из пяти поколений с аутосомно-доминантной формой тугоухости и шумом в ушах. Была оценена функция слухового и вестибулярного аппарата, а также проведено клиническое секвенирование экзома у пациентов. Далее с использованием метода Сэнгера был выполнен анализ сегрегации обнаруженных генетических вариантов с тугоухостью в исследуемой семье.

Результаты: Тугоухость у всех лиц из исследуемой семьи имела постлингвальный, прогрессирующий характер и касалась главным образом высоких частот. Не обнаружены нарушения фнукционирования вестибулярного аппарата. В генетических исследованиях идентифицирован очень редкий патогенный вариант p.Ile374Thr в гене COCH, полностью сегрегированный с болезнью в анализируемой семье.

Выводы: Наши исследования являются независимым подтверждением патогенной роли варианта p.Ile374Thr гена СОСН в возникновении тугоухости. Кроме тугоухости пациенты с патогенными вариантами гена СОСН могут также страдать от шума в ушах и нарушений равновесия.

Ключевые слова: $C O C H$, DFNA9, аутосомно-доминантная тугоухость, секвенирование следующего поколения.

\section{POSTLINGWALNY NIEDOSŁUCH ODBIORCZY SPOWODOWANY BARDZO RZADKIM PATOGENNYM WARIANTEM COCH}

\section{Streszczenie}

Wprowadzenie: Gen COCH kodujący kochlinę ma wysoką ekspresję w uchu wewnętrznym, ale dokładna funkcja fizjologiczna kodowanego przez ten gen białka wciąż pozostaje nieznana. Patogenne warianty zlokalizowane w genie $\mathrm{COCH}$ powodują niedosłuch dziedziczony w sposób autosomalny dominujący z możliwym zajęciem układu przedsionkowego.

Materiał i metody: Do badań włączono pięciopokoleniową rodzinę z autosomalnym dominującym ubytkiem słuchu i szumami usznymi. Oceniono funkcję narządu przedsionkowo-ślimakowego oraz w próbce DNA probanda przeprowadzono sekwencjonowanie eksomu klinicznego. Następnie wykonano analizę segregacji wykrytych wariantów genetycznych z niedosłuchem w badanej rodzinie.

Wyniki: Niedosłuch u wszystkich osób z badanej rodziny miał charakter postlingwalny, postępujący i dotyczył głównie wysokich częstotliwości. Nie wykryto zaburzeń funkcjonowania układu przedsionkowego. W badaniach genetycznych zidentyfikowano bardzo rzadko występujący wariant patogenny p.Ile374Thr genu $C O C H$, który w pełni segregował z chorobą.

Wnioski: Nasze badania stanowią niezależne potwierdzenie patogennej roli wariantu p.Ile374Thr genu COCH w powstawaniu niedosłuchu. Oprócz niedosłuchu, pacjenci z wariantami patogennymi genu $C O C H$ mogą również odczuwać szumy uszne i zaburzenia równowagi.

Słowa kluczowe: $\mathrm{COCH}$, DFNA9, niedosłuch autosomalny dominujący, sekwencjonowanie następnej generacji

\section{Introduction}

Hearing loss (HL) is the most common birth defect affecting about 1-6/1000 newborns and the most common disability of human senses in developed countries [1]. It may be caused by a number of different factors, including genetic as well as environmental factors e.g. severe prematurity, congenital rubella, mumps or cytomegalovirus infection, severe neonatal hyperbilirubinaemia, or exposure to ototoxic drugs or noise [2]. It has been estimated that genetic factors may account for almost $50 \%$ of all HL cases [3]. The genetic background of HL is complex and heterogeneous. So far, pathogenic variants in merely 100 different genes have been identified in patients with HL (www.herediataryhearingloss.org; accessed 10/2017). The majority of cases with genetically determined HL is represented by those with an autosomal recessive (AR) mode of inheritance $(80 \%)$, and this type of HL is usually prelingual and severe to profound [4].
Another important type of HL is that inherited in an autosomal dominant (AD) manner. AD HL accounts for almost $20 \%$ of HL cases, is usually progressive, and manifests itself later in life [4]. To date, 59 loci have been found to cause AD HL but only 36 genes have been described (www.herediataryhearingloss.org; accessed 10/2017). A significant number of these genes have been identified in recent years with the use of massively parallel sequencing methods [5]. One of the genes commonly tested in patients with the dominant postlingual form of $\mathrm{HL}$ is $\mathrm{COCH}$.

The $\mathrm{COCH}$ gene is located at $14 \mathrm{q} 12$ and encodes cochlin, an extracellular protein highly expressed in the inner ear, particularly in the habenula perforata, in fibrocytes of the spiral limbus, spiral ligament, modiolus, and stromal cells of the crista and macula, as well as in vestibular nerve channels $[6,7]$. COCH protein constitutes almost $70 \%$ of all inner ear proteins and seems to play an important role in hearing, but its exact function remains 




Figure 1. Family pedigree. The proband is marked with an arrow. Affected individuals are indicated by black symbols, unaffected individuals are indicated by open symbols; presymptomatic carrier is indicated by an open symbol with vertical line, diagonal line denotes deceased individuals

unknown [8]. The full-length $\mathrm{COCH}$ protein is made up of 550 amino acids and comprises 3 main domains: a LCCL domain highly homologous to factor C of Limulus, and two von Willebrand factor A (vWFA) domains $[9,10]$. Pathogenic variants identified in the $\mathrm{COCH}$ gene are associated with AD HL (DFNA6; OMIM \# 601369), with onset ranging from the $2^{\text {nd }}$ to $6^{\text {th }}$ decade of life [11]. At the beginning high frequencies are affected, with progression of HL slowing later in life [12]. Based on localization of the pathogenic variants to particular $\mathrm{COCH}$ domains, HL may be the only symptom in patients, or it may be accompanied by vestibular dysfunction and balance problems $[11,13]$.

In this study we have searched for the genetic cause of HL in a five-generation Polish family. We have applied a high throughput sequencing method and identified a very rare $\mathrm{COCH}$ pathogenic variant.

\section{Material and Methods}

\section{Patients and clinical diagnosis}

A five-generation Polish family with a history of HL over four generations was recruited for the study at the Department of Genetics, Institute of Physiology and Pathology of Hearing. The study included four patients with HL (III.2, III.4, IV.1, IV.7) and four unaffected individuals (III.3, IV.5, V.1, V.2) (Figure 1). All tested subjects gave informed consent for participation in the study, in accordance with the tenets of the Declaration of Helsinki.
Assessment of auditory function in the index patient (IV.1) was performed with pure-tone audiometry. Hearing thresholds for air and bone conduction were determined at frequencies of $125-8000 \mathrm{~Hz}$ and $500-4000 \mathrm{~Hz}$ with an AC40 clinical audiometer (Interacoustics, Middelfart, Denmark) and a 10/5 dB descending-ascending threshold estimation procedure [14].

In patient IV.7 neurootological clinical examination was performed. Objective vestibular function was measured using cervical and ocular evoked myogenic potentials (cVEMP, oVEMP) recorded with $500 \mathrm{~Hz}, 97 \mathrm{dBnHL}$ airconducted sound stimulation (EclipsVemp, Interacoustics, Assens, Denmark).

\section{Targeted next-generation sequencing}

Genomic DNA was isolated from whole blood samples with a standard salting out procedure. Concentration of the genomic DNA was determined with a Qubit HS Assay Kit using a Qubit 2.0 fluorometer (Invitrogen, Carlsbad, CA, USA). In the index patient (IV.1), clinical exome sequencing (TruSightOne, Illumina, Cambridge, UK) was performed according to the manufacturer's protocol. The sample was run on a MiSeq (Illumina) using $2 \times 150 \mathrm{bp}$ paired-end reads. Bioinformatics analysis was performed as described previously [15]. Selected variants were annotated with Annovar and converted to MS Access format for further analyses. Integrative Genomics Viewer was used to inspect selected reads and validate candidate variants [16]. 
A

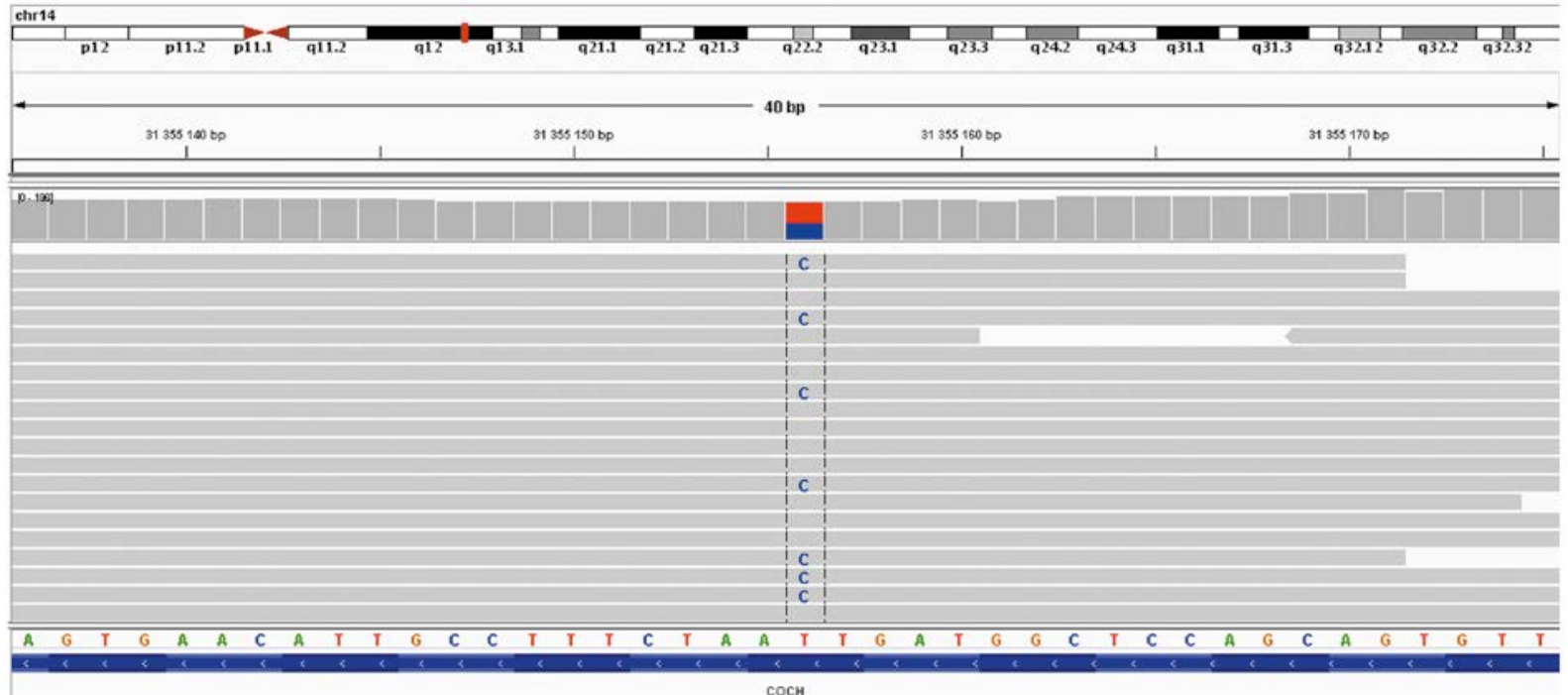

B

\begin{tabular}{|c|c|c|c|c|c|c|c|c|c|c|c|c|}
\hline & & & 209 & & & & & 234 & & & & \\
\hline ef: $T \quad T$ & G & C & C & $\mathrm{T}$ & $\mathrm{T}$ & $\mathrm{T}$ & C & $\mathrm{T}$ & $\mathrm{T}$ & C & C & A \\
\hline$n \mathrm{~T} \quad \mathrm{~T}$ & G & C & C & $\mathrm{T}$ & $\mathrm{T}$ & $\mathrm{T}$ & C & $\mathrm{T}$ & $T$ & & & \\
\hline
\end{tabular}

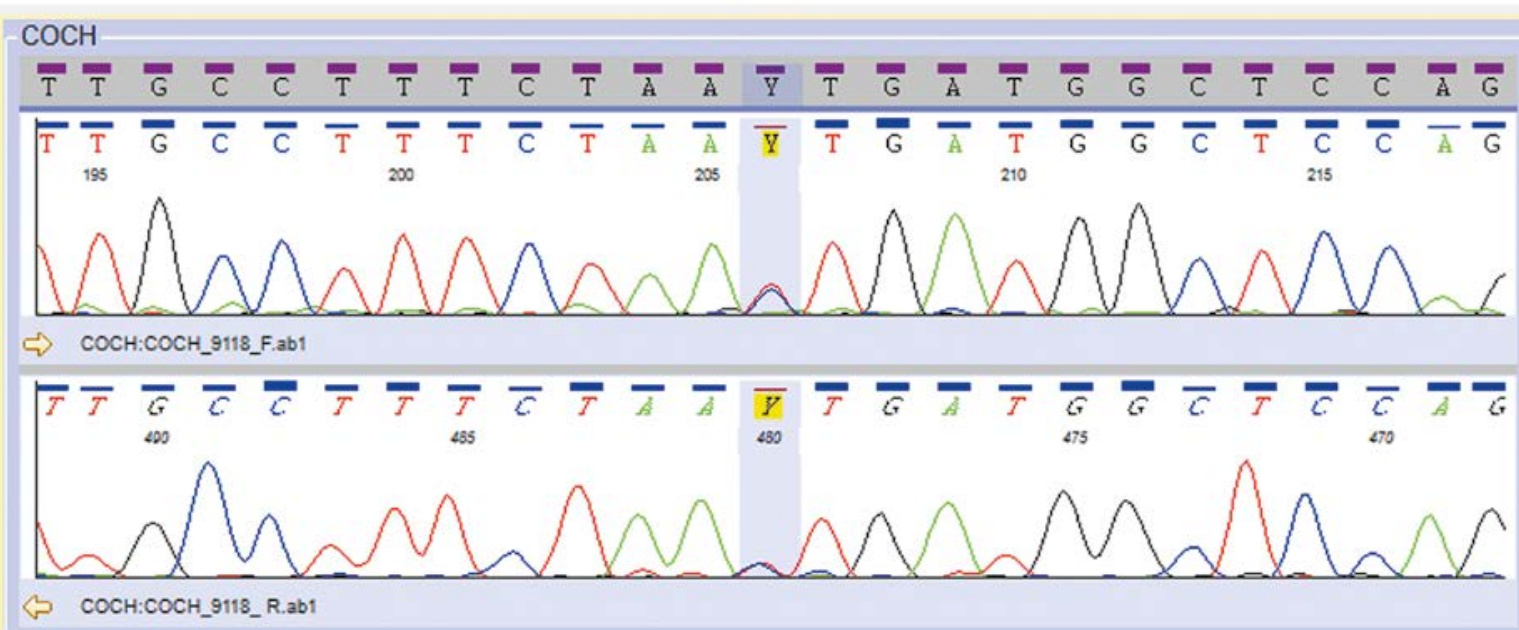

Figure 2. (A) NGS results visualized with Integrative Genomic Viewer software. (B) The corresponding chromatogram showing a heterozygous thymine to cytosine transition (c.1555T >C) detected by Sanger sequencing

Our analysis pipeline included variant population frequencies from the database of the 1000 Genomes Project [17], the NHLBI GO Exome Sequencing Project (ESP) (https:// esp.gs.washington.edu/drupal), and the Exome Aggregation Consortium (ExAC) (http://exac.broadinstitute.org) (accessed 10/2017). Functional pathogenicity predictions for non-synonymous variants were performed using SIFT [18], PolyPhen-2 [19], and MutationTaster2 [20] computational algorithms.

\section{Sanger sequencing}

Presence of the candidate pathogenic variant was confirmed by Sanger sequencing. The forward primer 5' TGAAACATTCAGGATTTTCCAGT and reverse primer 5' - ATGAGATGAGTAGGGCTGCTTTA were used for amplification of exon 11 of the $\mathrm{COCH}$ gene. Next, PCR products labeled with BigDye Termination cycle sequencing kit v3.1 (Applied Biosystems, Foster City, CA, USA) were sequenced with a 3500xL Genetic Analyzer (Applied Biosystems) and analyzed using Variant Reporter Software v1.1 (Applied Biosystems).

\section{Results}

A five-generation Polish family with postlingual, progressive HL and tinnitus was recruited for the study. The pedigree of this family showed a typical autosomal dominant pattern of inheritance, i.e. there was a maleto-offspring transition of HL and affected adult individuals were present in every generation (vertical pattern of inheritance). 
right ear

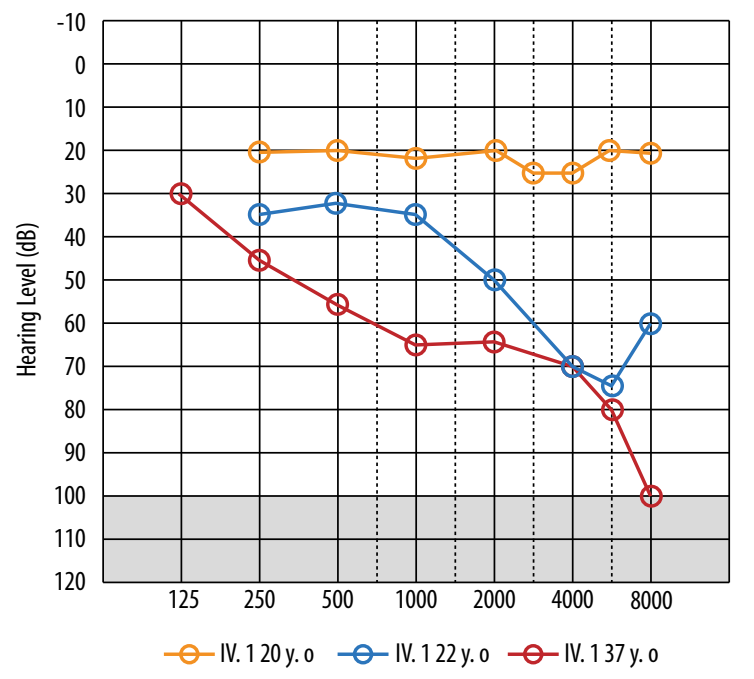

left ear

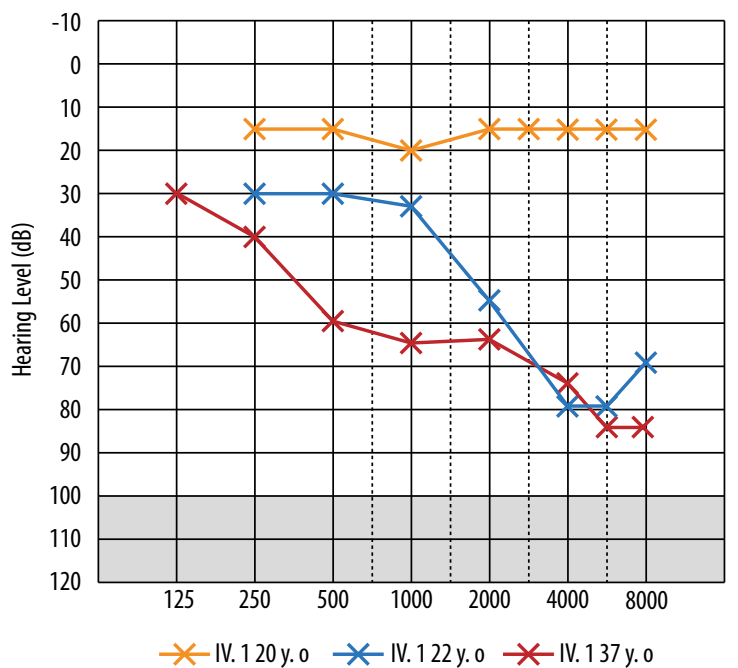

Figure 3. Pure tone audiometry of the index patient (IV.1) showing the progression of HL

Affected individuals had moderate to severe high frequency HL with a mean age of onset of 28.25 years (range, 15-47 years). In the index patient (IV.1), HL was diagnosed at the age of 22 and progressed gradually. Initially, the high frequency HL was followed by the involvement of mid frequencies. The latest audiological assessment at the age of 39 revealed mild to moderate HL at low frequencies, moderate $\mathrm{HL}$ at mid frequencies, and severe to profound HL at high frequencies (Figure 3). The patient suffered from tinnitus from the age of 15 years. He was fitted with binaural hearing aids at the age of 22 and since then he has reported improved speech intelligibility and reduced tinnitus.

Neither the index patient nor the other affected family members reported balance problems. This is consistent with the results of the vestibular function evaluation. Normal cVEMP and oVEMP responses were recorded in patient IV.7.

On the DNA sample from the index patient we have performed targeted next-generation sequencing of more than 4800 genes and identified 37,392 different genetic variants. After exclusion of variants in the non-coding regions (intronic, $3^{\prime}$, and $5^{\prime}$ UTR) and synonymous alterations we focused on variants with an allele frequency lower or equal to 0.01 . Next, we selected variants located in genes involved in the development of HL (Table 1).

A detailed analysis of how the selected variants are inherited and their corresponding phenotype resulted in the prediction of one candidate disease-causing variant - a heterozygous transition c.1115T >C (NM_004086.2) located in the $\mathrm{COCH}$ gene (Figure $2 \mathrm{~A}, \mathrm{~B}$ ). This change results in a substitution of isoleucine to threonine at position 372 (NP_004077.1:p.Ile372Thr) of the COCH protein. Segregation analysis confirmed that p.Ile374Thr was present in all affected subjects but also in the normal hearing son of the proband (8 y.o.). The genetic alteration was not present in other unaffected relatives.
The p.Ile372Thr pathogenic variant was not found in the analyzed population databases. To date, the p.Ile372Thr variant has been described in only two Japanese famielies with AD HL [13] and has been reported in the Human Gene Mutation Database (www.hgmd.cf.ac.uk/ac/index. php) with the accession number CM152070. In silico analysis predicted a deleterious effect of the detected variant with the following scores: PolyPhen-2 (score 0.978), SIFT (score 0.01), and MutationTaster2 (score 0.998).

\section{Discussion}

In this study we have identified the first pathogenic variant in the $\mathrm{COCH}$ gene in a Polish family. We have applied targeted next-generation sequencing to more than 4800 genes and detected a very rare $\mathrm{COCH}$ genetic variant that was not present in any of the analyzed population databases. These results, together with the data from computational approaches, showed that the genetic alteration has a deleterious effect on $\mathrm{COCH}$ protein structure and function. This strongly indicates that the identified variant represents a HL-causing change. This assumption is further confirmed by a segregation analysis of the genetic alteration with HL in the examined family. Testing a large number of genes in the index patient also resulted in the identification of five potentially pathogenic variants in genes, other than $\mathrm{COCH}$, that were previously associated with HL. Based on the phenotype reported for these variants and their mode of inheritance, they have been excluded as causative for the nonsyndromic postlingual AD HL observed in the studied family.

The $C O C H$ c. $1115 \mathrm{~T}>\mathrm{C}$ variant identified here is predicated to result in a p.Ile372Thr amino acid change. It localizes in the vWFA domain of the $\mathrm{COCH}$ protein and leads to substitution of highly conserved leucine to threonine. Pathogenic variants affecting this domain cause postlingual progressive HL without dysfunction of the vestibular system [21]. 
Table 1. Potentially pathogenic sequence variants detected by next-generation sequencing in the index patient

\begin{tabular}{|c|c|c|c|c|c|c|}
\hline SNP ID & Gene name & Variant & Transcript name & Zygosity & Phenotype & $\begin{array}{l}\text { Inheritance } \\
\text { pattern }\end{array}$ \\
\hline \multirow{3}{*}{ rs55816283 } & \multirow{3}{*}{ COL4A3 } & \multirow{3}{*}{$\begin{array}{c}\text { C.3325C>T } \\
\text { p.Pro1109Ser }\end{array}$} & \multirow{3}{*}{ NM_000091.4 } & \multirow{3}{*}{ Het } & $\begin{array}{c}\text { Alport syndrome, autosomal } \\
\text { dominant }\end{array}$ & $A D$ \\
\hline & & & & & $\begin{array}{l}\text { Alport syndrome, autosomal } \\
\text { recessive }\end{array}$ & AR \\
\hline & & & & & Hematuria, benign familial & $A D$ \\
\hline \multirow{3}{*}{ rs77964815 } & \multirow{3}{*}{ COL4A3 } & \multirow{3}{*}{$\begin{array}{l}\text { c. } 4484 A>G \\
\text { p.Gln1495Arg }\end{array}$} & \multirow{3}{*}{ NM_000091.4 } & \multirow{3}{*}{ Het } & $\begin{array}{c}\text { Alport syndrome, autosomal } \\
\text { dominant }\end{array}$ & $A D$ \\
\hline & & & & & $\begin{array}{l}\text { Alport syndrome, autosomal } \\
\text { recessive }\end{array}$ & AR \\
\hline & & & & & Hematuria, benign familial & $A D$ \\
\hline \multirow[b]{2}{*}{ rs201320592 } & \multirow[b]{2}{*}{ POLR1C } & \multirow[b]{2}{*}{$\begin{array}{l}\text { c.395G>A } \\
\text { p.Gly132Asp }\end{array}$} & \multirow[b]{2}{*}{ NM_203290.2 } & \multirow[b]{2}{*}{ Het } & Treacher Collins syndrome 3 & $A R$ \\
\hline & & & & & $\begin{array}{l}\text { Leukodystrophy, } \\
\text { hypomyelinating, } 11\end{array}$ & AR \\
\hline \multirow{4}{*}{ rs199701987 } & \multirow{4}{*}{ MET } & \multirow{4}{*}{$\begin{array}{l}\text { c.406G>A } \\
\text { p.Val136Ile }\end{array}$} & \multirow{4}{*}{ NM_001127500.1 } & \multirow{4}{*}{ Het } & $\begin{array}{l}\text { ?Deafness, autosomal recessive } \\
97\end{array}$ & AR \\
\hline & & & & & $\begin{array}{l}\text { Hepatocellular carcinoma, } \\
\text { childhood type, somatic }\end{array}$ & n.a. \\
\hline & & & & & $\begin{array}{l}\text { Renal cell carcinoma, papillary, } \\
1 \text {, familial and somatic }\end{array}$ & n.a. \\
\hline & & & & & $\begin{array}{l}\text { Osteofibrous dysplasia, } \\
\text { susceptibility to }\end{array}$ & $A D$ \\
\hline n.a. & $\mathrm{COCH}$ & $\begin{array}{l}\text { c. } 1115 \mathrm{~T}>\mathrm{C} \\
\text { p.lle372Thr }\end{array}$ & NM_004086.2 & Het & $\frac{\text { Deafness, autosomal dominant }}{\underline{9}}$ & $A D$ \\
\hline \multirow{3}{*}{ rs11570344 } & \multirow{3}{*}{ EDN3 } & \multirow{3}{*}{$\begin{array}{l}\text { c.560_561insA } \\
\text { p.Glu187_Lys188fs }\end{array}$} & \multirow{3}{*}{ NM_207034.2 } & \multirow{3}{*}{ Het } & $\begin{array}{l}\text { Central hypoventilation } \\
\text { syndrome, congenital }\end{array}$ & $A D$ \\
\hline & & & & & $\begin{array}{l}\text { Waardenburg syndrome, type } \\
4 \mathrm{~B}\end{array}$ & $A R, A D$ \\
\hline & & & & & $\begin{array}{l}\text { Hirschsprung disease, } \\
\text { susceptibility to, } 4\end{array}$ & $A D$ \\
\hline
\end{tabular}

SNP ID, single nucleotide polymorphism identification number, AD, autosomal dominant; AR, autosomal recessive; Het heterozygous; n.a., no data available. Underlined are Human Gene Mutation Database phenotypes attributed to particular variants

This $\mathrm{COCH}$ c.1115T $>\mathrm{C}$ genetic alteration was first identified in Japanese families that also had progressive HL without vertigo [13]. In contrast to our family, the Japanese patients had a higher age of HL onset (third vs fourth/fifth decade of life, respectively). In all families there was interfamilial variability in the age of HL onset (15-47 y.o. in the Polish vs 33-42 y.o. in the Japanese patients). One of the unaffected offspring of the index patient was also found to carry the $\mathrm{COCH}$ c. $1115 \mathrm{~T}>\mathrm{C}$ variant. Currently, he is 8 y.o. and we presume he will most probably develop HL with age.

In the Polish index patient there was a strong association of exposure to noise with the occurrence and progression of his HL, although other affected family members did not report acoustic trauma. While this is an interesting observation, currently there are no data on the triggering role of noise in the development and/or progression of $\mathrm{HL}$ due to $\mathrm{COCH}$ pathogenic variants. Noise may be an independent factor causing HL and one may speculate that the earlier age of HL onset observed in our family may have been a consequence of exposure to noise. No information on the occurrence of tinnitus in the Japanese family was provided.
The index patient is currently using hearing aids, but considering the progressive nature of his HL in the next few years he may require a cochlear implant. Based on the partial deafness treatment strategy proposed by H. Skarżyński et al., the optimal treatment for this patient seems to be electric-acoustic stimulation (EAS) of the auditory system using a hearing aid combined with a cochlear implant. In EAS, low frequency hearing is amplified by hearing aids and combined in the same ear with electric stimulation from the cochlear implant [22, 23].

Our study provides an independent confirmation of the pathogenic role of $\mathrm{COCH}$ c.1115T $>\mathrm{C}$ in HL. It is important to underline that in addition to HL individuals with COCH HL-causing variants may also suffer from tinnitus and vertigo. On the other hand, information on the presence of tinnitus and/or vertigo may be beneficial for proper targeting of molecular genetic testing.

\section{Acknowledgements}

This work was supported by the Institute of Physiology and Pathology of Hearing and the Polish National Science Center grant no. 2016/22/E/NZ5/00470. 


\section{References}

1. Tucci D, Merson MH, Wilson BS. A summary of the literature on global hearing impairment: current status and priorities for action. Otol Neurotol, 2010; 31(1): 31-41.

2. Dawes P, Platt H, Horan M, Ollier W, Munro K, Pendleton N, et al. No association between apolipoprotein $\mathrm{E}$ or N-acetyltransferase 2 gene polymorphisms and age-related hearing loss. Laryngoscope, 2015; 125(1): E33-8.

3. Jecmenica J, Bajec-Opancina A, Jecmenica D. Genetic hearing impairment. Child's nervous system. ChNS, 2015; 31(4): 515-9.

4. Smith RJH, Shearer AE, Hildebrand MS. Deafness and hereditary hearing loss overview. GeneReviews, 1999 [updated 2014 Jan 9]. Available from: http://www.ncbi.nlm.nih.gov/ books/NBK1434/.

5. Vona B, Nanda I, Hofrichter MA, Shehata-Dieler W, Haaf T. Non-syndromic hearing loss gene identification: A brief history and glimpse into the future. Mol Cellular Probes, 2015; 29(5): 260-70.

6. Robertson NG, Resendes BL, Lin JS, Lee C, Aster JC, Adams JC, et al. Inner ear localization of mRNA and protein products of $\mathrm{COCH}$, mutated in the sensorineural deafness and vestibular disorder, DFNA9. Human Mol Genetics, 2001; 10(22): 2493-500.

7. Parzefall T, Frohne A, Koenighofer M, Kirchnawy A, Streubel $\mathrm{B}$, Schoefer $\mathrm{C}$, et al. Identification of a rare $\mathrm{COCH}$ mutation by whole-exome sequencing: implications for personalized therapeutic rehabilitation in an Austrian family with non-syndromic autosomal dominant late-onset hearing loss. Wien Klin Wochenschr, 2017.

8. Ikezono T, Omori A, Ichinose S, Pawankar R, Watanabe A, Yagi T. Identification of the protein product of the Coch gene (hereditary deafness gene) as the major component of bovine inner ear protein. Biochimica Biophysica Acta, 2001; 1535(3): 258-65.

9. Robertson NG, Skvorak AB, Yin Y, Weremowicz S, Johnson $\mathrm{KR}$, Kovatch KA, et al. Mapping and characterization of a novel cochlear gene in human and in mouse: a positional candidate gene for a deafness disorder, DFNA9. Genomics, 1997; 46(3): 345-54

10. de Kok YJ, Bom SJ, Brunt TM, Kemperman MH, van Beusekom E, van der Velde-Visser SD, et al. A Pro51Ser mutation in the $\mathrm{COCH}$ gene is associated with late onset autosomal dominant progressive sensorineural hearing loss with vestibular defects. Human Mol Genetics, 1999; 8(2): 361-6.
11. Robertson NG, Lu L, Heller S, Merchant SN, Eavey RD, McKenna $\mathrm{M}$, et al. Mutations in a novel cochlear gene cause DFNA9, a human nonsyndromic deafness with vestibular dysfunction. Nature Genetics, 1998; 20(3): 299-303.

12. Jung J, Kim HS, Lee MG, Yang EJ, Choi JY. Novel COCH p.V123E Mutation, Causative of DFNA9 sensorineural hearing loss and vestibular disorder, shows impaired cochlin posttranslational cleavage and secretion. Human Mutation, 2015; 36(12): 1168-75.

13. Tsukada K, Ichinose A, Miyagawa M, Mori K, Hattori M, Nishio SY, et al. Detailed hearing and vestibular profiles in the patients with COCH mutations. Annals Otol, Rhinol Laryngol, 2015; 124 Suppl 1: 100S-110S.

14. Recommended procedure for pure-tone bone-conduction audiometry without masking using a manually operated instrument - technical note. Br J Audiol, 1985; 19(4): 281-2.

15. Oldak M, Ozieblo D, Pollak A, Stepniak I, Lazniewski M, Lechowicz U, et al. Novel neuro-audiological findings and further evidence for TWNK involvement in Perrault syndrome. J Transl Med, 2017; 15(1): 25.

16. Robinson JT, Thorvaldsdottir H, Winckler W, Guttman M, Lander ES, Getz G, et al. Integrative genomics viewer. Nat Biotechnol, 2011; 29(1): 24-6.

17. Genomes Project C, Abecasis GR, Auton A, Brooks LD, DePristo MA, Durbin RM, et al. An integrated map of genetic variation from 1,092 human genomes. Nature, 2012; 491(7422): 56-65.

18. Kumar P, Henikoff S, Ng PC. Predicting the effects of coding non-synonymous variants on protein function using the SIFT algorithm. Nat Protoc, 2009; 4(7): 1073-81.

19. Adzhubei I, Jordan DM, Sunyaev SR. Predicting functional effect of human missense mutations using PolyPhen-2. Curr Protoc Hum Genet, 2013; Chapter 7: Unit 720.

20. Schwarz JM, Cooper DN, Schuelke M, Seelow D. MutationTaster2: mutation prediction for the deep-sequencing age. Nat Methods, 2014; 11(4): 361-2.

21. Gallant E, Francey L, Fetting H, Kaur M, Hakonarson H, Clark D, et al. Novel COCH mutation in a family with autosomal dominant late onset sensorineural hearing impairment and tinnitus. Am J Otolaryngol, 2013; 34(3): 230-5.

22. Skarzynski H, Lorens A, Piotrowska A. A new method of partial deafness treatment. Med Sci Mon, 2003; 9(4): CS20-4.

23. Skarzynski H, Lorens A, Piotrowska A, Anderson I. Partial deafness cochlear implantation in children. Int J Ped Otorhinolaryngol, 2007; 71(9): 1407-13. 
